\title{
Asynchronous phase rotor motor in reactive power compensator mode
}

\author{
Yu. Kovalova \\ O.M. Beketov National Univer- \\ sity of Urban Economy in \\ Kharkiv, Ukraine \\ E-mail: kovalova.jv@gmail.com
}

\author{
V. Kovalov \\ National Technical University \\ "Kharkiv Polytechnic Institute", \\ Ukraine \\ E-mail: j.k@ scientist.com
}

\author{
V. Feteev \\ O.M. Beketov National Univer- \\ sity of Urban Economy in \\ Kharkiv, Ukraine \\ E-mail: kovalova.jv@gmail.com
}

\begin{abstract}
- reactive power compensation remains an important factor for energy keeping. Usually, kondenser banks are used for compensation, the disadvantage of which is the difficulty of regulating the capacitance value with variable consumption of reactive power. For smooth regulation of reactive power, synchronous motors and semiconductor static compensators are used. But the search for using other alternative means of reactive power compensation remains relevant.
\end{abstract}

As an alternative compensator for reactive power, the article proposes the use of an induction motor with dual power supply. This problem is solved in two stages. At the first stage, a theoretical analysis of the process of generating reactive power by a dual-supply induction motor is considered. With dual power supply, a sinusoidal voltage is supplied to the stator, and a direct voltage is supplied to the rotor. In this case, the rotor winding turns into a DC electromagnet, which rotates synchronously with the rotational magnetic field created by the fixed stator windings

The magnetic field of the rotor winding moves relative to the stationary stator windings with the speed of the moving magnetic field of the stator. Their magnetic axes coincide because the engine is idling. To justify the reactive power generation mode, vector diagrams of the stator and rotor voltages and currents were compiled for three dual-supply asynchronous motor operation modes: 1) reactive power consumption mode, 2) non-consumption mode and 3) generation mode.

At the second stage, a power circuit and a control circuit for a dual-supply asynchronous motor are developed. The power circuit includes a phase meter in the stator electric circuit to measure the phase angle of the stator current from voltage, an ammeter of the electromagnetic system to measure the magnitude of the stator winding current. The rotor circuit includes additional active resistors for accelerating the motor to under synchronous speed, a direct cur-rent electromagnetic relay that measures the magnitude of the electromotive force of the rotor winding. A thyristor rectifier with feedback on the rotor winding current has been adopted as a direct current source.

A relay circuit has been developed for controlling a dualsupply induction motor. Experimental research have been carried out to determine the dependence of the stator current and its phase shift relative to the stator voltage on the value of the rotor winding current.

According to the results of the experiments, a graph of the dependence of the stator winding current on the value of the direct current of the rotor winding is constructed. From the graph it follows that with increasing rotor cur-rent, the stator current changes. First, the stator current decreases to a minimum value and then increases. This means that the type of stator current varies from inductive to active and to capacitive.

Thus, the use of an induction motor for generating reactive power has advantages over capacitor banks, as it allows its smooth controlment. But the power loss for generating reactive energy is greater than for capacitor banks.

Keywords - induction motor, phase rotor, duble supply, reactive power, compensation

\section{FORMULATION OF THE PROBLEM}

Reactive power compensation remains one of the important factors for energy conservation. Typically, capacitor batteries are used to compensate for reactive power, the disadvantage of which is the difficulty of adjusting the capacity for variable reactive power consumption. Synchronous motors and semiconductor static compensators provide traditionally smooth reactive power control. But it remains relevant to use other alternative means of reactive power compensation.

\section{ANALYSIS OF RECENT RESEARCH AND PUBLICATIONS}

In [1-3] the analysis of electric drive modes for realization of their energy saving properties is carried out, but the possibilities of an induction motor as a generator of jet power are not considered. Generation of reactive power by an asynchronous motor with a phase rotor occurs in dual power mode, when a sinusoidal voltage is applied to the stator windings, and an adjustable DC voltage is applied to the rotor windings. In [4-6], the analysis of the components of the power balance in networks with nonlinear load and methods of reactive power compensation. In [7], an analysis of the energy-saving properties of an induction motor with a short-circuited rotor when powered by a semiconductor frequency converter. In [8-10], a theoretical analysis of the reactive power compensation process with the use of active filters based on inverters was carried out.

\section{THE PURPOSE OF THE ARTICLE}

Theoretical substantiation of the principle of generating reactive power by an asynchronous motor with a phase rotor, development of a control scheme and experimental study of the dependence of the stator jet current on the direct current of the rotor. 
IV. BASIC RESEARCH MATERIALS.

The goal is solved in two stages. In the first stage, the process of generating jet power into the grid is considered. With dual power supply, the stator is supplied with a sinusoidal voltage and a constant voltage on the rotor. In this case, the rotor is converted into a direct current electromagnet, which rotates synchronously with the rotating magnetic field of the fixed stator windings. The magnetic field of the rotor winding moves relative to the fixed stator windings with the speed of the moving magnetic field of the stator. Their magnetic axes coincide because the engine is idle. Consider the point in time when the south pole of the rotor is below the north pole of the stator (Fig. 1). The magnetic flux of the rotor intersects the fixed stator winding of phase $\mathrm{A}$ and induces in it the electromotive force (EMF) of rotation of the rotor, which according to Faraday's law is $E_{r}=C \phi_{r} \omega_{r}$. The EMF of the rotor is directed opposite to the voltage of the network, since it is created by the south pole of the magnetic field of the rotor relative to the magnetic field winding of phase A of the stator. The equilibrium equation of the stator phase is of the form

$$
\dot{U}_{s}-\dot{E}_{r}=R_{s} \dot{I}_{s r}+j X_{s} \dot{I}_{s r},
$$

where $U_{s}-$ stator phase winding voltage; EMF;

$I_{r}$ - the current in the stator winding from the rotor

$I_{s r}-$ the resulting stator current as the vector sum of the stator current and the current from the rotor EMF;

$X_{s}=X_{s o}+X_{s \sigma}-$ the resulting inductive resistance of the stator phase winding as the sum of the main and the scattering.

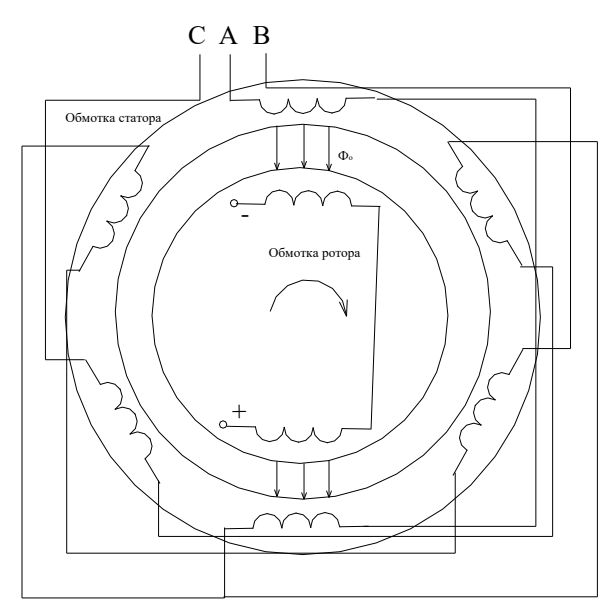

Fig. 1. Simplified section of the engine

Equation (1) corresponds to the vector diagram in Fig. 2 , where the stator current is shown as the vector sum of its active and reactive components $I_{s}=I_{s a}+I_{\text {sp. }}$.

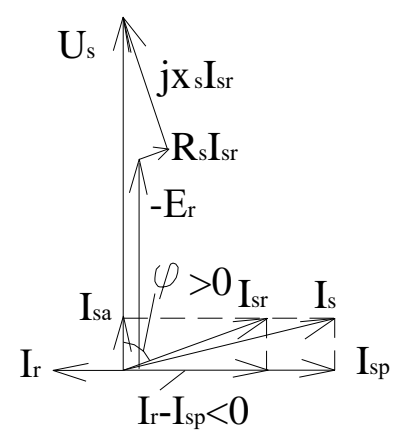

Fig. 2. Vector diagram of voltages and currents in the mode of consumption of jet power

The magnitude of the rotor EMF is less than the network voltage, and therefore the engine consumes reactive power. In this case, the angle of shear current from the voltage behind $\varphi>0$. With a further increase in the direct current of the rotor the EMF of the rotor increases and becomes equal to the stator voltage. In this case, the current in the stator winding from the rotor EMF is equal to the reactive component of the stator current, that is, the motor consumes the active current $\mathrm{I}_{\mathrm{sa}}$ and does not consume reactive power from the network, as shown in the vector diagram in Fig. 3

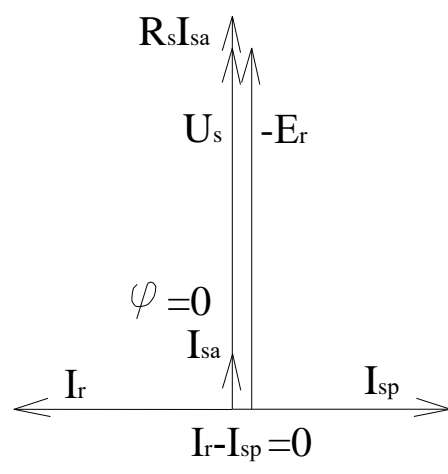

Fig. 3. Vector diagram in stator winding reactive power compensation mode

As the rotor current increases further, the rotor EMF becomes larger than the stator EMF, and the current created by it becomes larger than the reactive component of the stator current. The resulting current is ahead of the voltage phase, ie the induction motor generates jet current into the network, as shown in the vector diagram in Fig. 4.

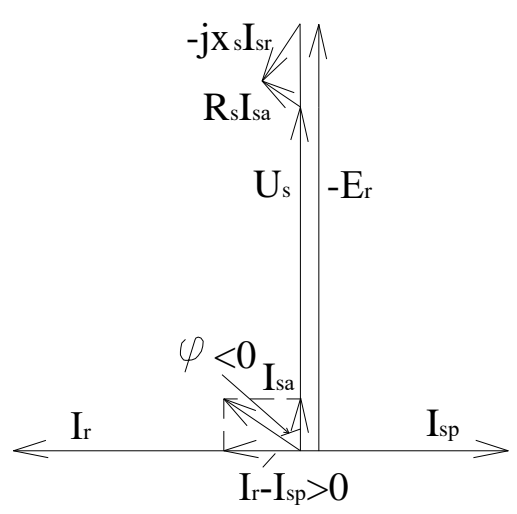

Fig. 4. Vector diagram in jet power generation mode 
Yu. Kovalova, V. Kovalov, V. Feteev, Вип.55, №02.

Thus, an induction motor with dual power can operate in three modes: to consume reactive power, not to consume and to generate it in the mains.

In the second stage, the power scheme and control scheme of the dual-power induction motor are shown, which are shown in Fig. 5 and Fig. 6. The power circuit includes an automatic switch QF1, measuring devices: phase meter $\mathrm{p} \varphi 1$ and ammeter $\mathrm{pA} 1$, asynchronous motor M1. An additional active support R1-R6, a time relay coil KT3, a controlled rectifier UZ1, the output of which the ammeter pA2 and a relay coil KA.

Starting the engine is a circuit control by pressing the button SB1, then triggered magnetic actuator KM1 and its power contacts KM1 connects the stator of the motor to the network.

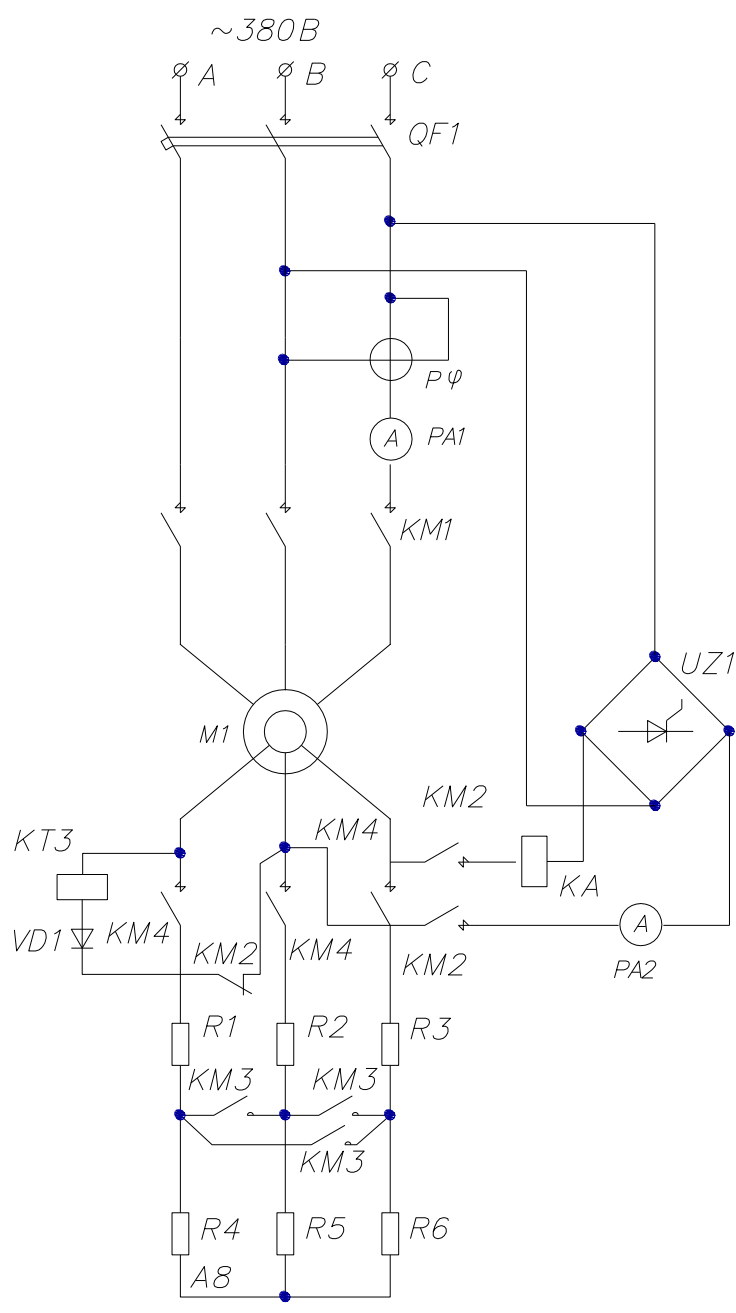

Fig. 5. Power scheme

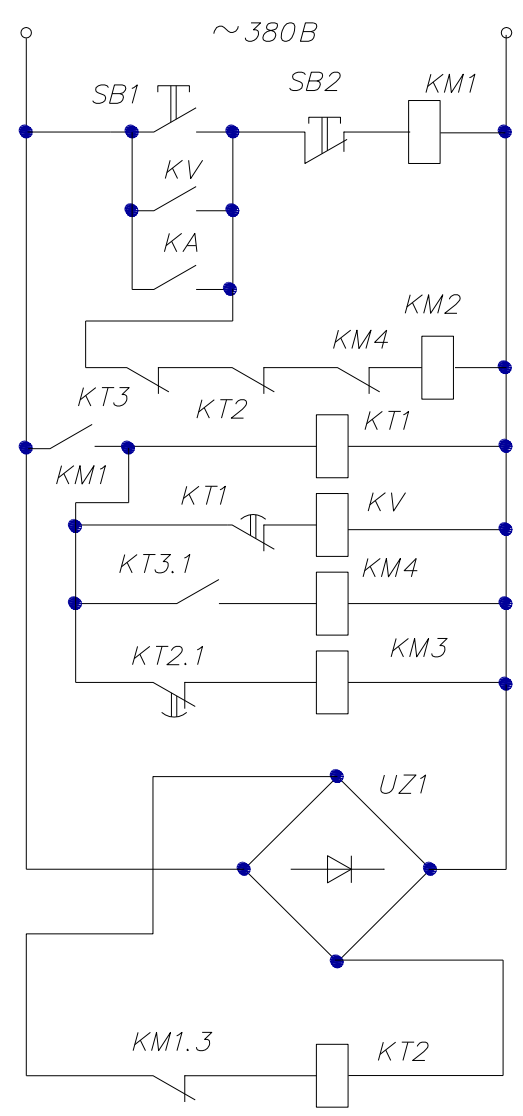

Fig. 6. The control scheme

Its KM1 block contact supplies voltage to the KT1 time relay coils and the KV voltage relay, and the KM1.3 block contact opens the $\mathrm{K} 2$ time relay coil circuit. The KV voltage relay is triggered and by its contact KV shunts the SB1 button. The magnetic field of the stator winding induces electromotive force (EMF) in the rotor windings and triggers the KTZ time relay, which with its KT3.1 contact activates the magnetic actuator KM4 coil under voltage, the power contacts of which connect the rotor winding with additional resistors R1-R6. Torque appears and the rotor starts accelerating, increasing angular velocity. With time, the anchor from the core of the KT2 time relay drops out and closes its KT2.1 contact in the circle of the KM3 magnetic actuator coil. After the KM3 is triggered, its KM3.1 contacts shunt additional resistance R4-R6, the engine continues acceleration according to the second artificial mechanical characteristic. As the rotor speed increases further, the EMF of the rotor decreases and at a speed value of about $95 \%$ of the synchronous speed, the anchor of the KT3 relay drops away from the core. This closes the contact KT3.2 in the circle of the coil magnetic actuator KM2 and opens the contact KT3.1 in the circle of the coil magnetic actuator KM4, power contacts KM4.1 which disconnect the supports R1-R6 from the rotor winding circuit, and block contacts KM4.2 close the power circuit of the KM2 magnetic actuator coil. After KM2 is triggered, its power contacts connect the rotor windings to the output of the thyristor rectifier VZ1, a constant current appears in the rotor circuit and the induction motor goes into dual power mode. The KA current relay is triggered, and by its contact the KA is bypassing the contacts of the SB1 button. Then, with time delay, the time relay KT1 triggers, opening its 
contacts KT1.1 in the circuit of the coil of the voltage relay $\mathrm{KV}$, and its contact $\mathrm{KV}$ is opened. If, in the time interval, the KT1 relay KA2 relay does not work, ie, the motor rotor does not reach at a synchronous speed, then its breaking contact de-energizes the voltage relay coil and the motor disconnects from the network.

On the basis of the developed scheme, experimental studies of the dependence of the stator current on the rotor current, which is shown in Fig. 7.

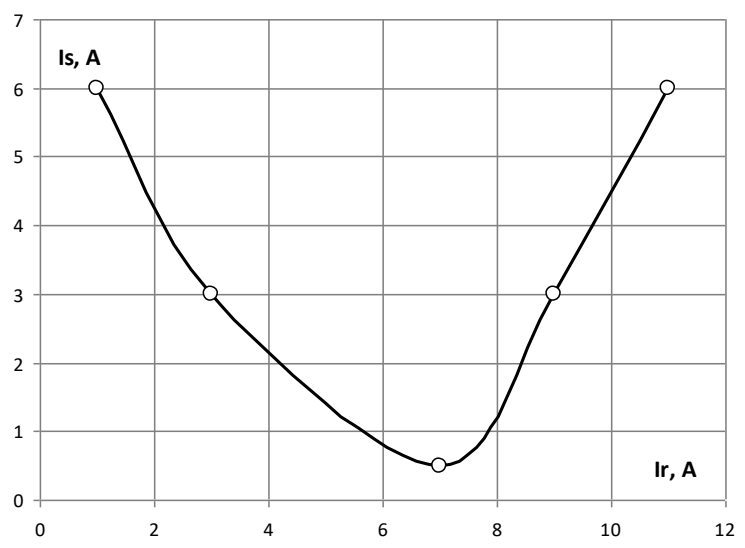

Fig. 7. Experimental graph of the dependence of the stator current on the direct current of the rotor

The graph shows that as the rotor current increases, the stator current decreases and the value of the rotor current 7A compensates for the reactive component of the stator current and consumes only the active current.

\section{CONCLUSIONS}

On the basis of the theoretical substantiation of the principle of operation of a double-powered asynchronous motor with phase-fed rotor, vector diagrams were obtained for three modes of operation of an asynchronous dualpower motor: 1) jet lag mode with lagging power factor; 2) full reactive power compensation mode with one power factor; 3) reactive power generation mode with ahead power factor. Circuit diagram for control of dual-power induction motor and dependence of stator current on rotor cur- rent. The use of an asynchronous motor with a phase rotor for generating reactive power has advantages over capacitor batteries because it allows its smooth regulation. But the power losses for the generation of reactive energy are bigger than for the capacitor batteries, so feasibility study is needed.

\section{REFERENCES}

[1] Barsky V. A., Beshta A. S., Gorbachev N. V., Zagirnyak M. V., Klepikov V. B., Lozinsky O. Yu., Mekhovich S. A., Peresada S. M., Sadovoy A. V., Tolochko O. I. (2013). Electric drive as an energy-keeing factor in the industry and housing and communal services of Ukraine. Energy Saving • Energy • Energy Auditing. Kharkov, No. 9(115), 2-11.

[2] Zakladny O. M., Prakhovnik A. V., Solovey O. I. Zakladny O. M. (2003). Energy keeping by means of industrial electric drive. K.: Condor, 408.

[3] R. D. Klug and Klaassen. (2005). High power medium voltage drives - Innovation, portfolio, trends. in Proc. Eur. Conf. Power Electron, Appl., 1-10.

[4] Vladimirov Yu. V. (2008). About the concept of reactive power compensation. Svitlotechnika \& Electroenergetika. Kh. : KhNAMG, № 3, 35-41.

[5] Govorov F. P., Govorov V. F. (2013). Reactive power compensation in urban electricity and lighting systems. Scientific works National Technical University in Kharkiv, Ukraine, Donetsk: DonNTU, № 1(14), 75-79.

[6] Peng F. (1998). Harmonic and reactive power compensation based on the generalized instantaneous reactive power theory for threephase four-wire systems. IEEE Trans Power Electronics. Vol. 13, № 6, 1174-1181.

[7] J. Rodriguez, S. Bernet, B. Wu, J.O. Ponu, and S. Kouro (2007). Multilevel voltage-source-converter topologies for industrial medium-voltage drivers. IEEE Trans. Ind. Electron., vol. 54, no. 6, 2930-2945.

[8] L.G. Franquelo, J. Rodriguez, J.I. Leon S. Kouro, R. Portillo and M. A. M. Prats. (2008). The age of multilevel converters arrives. IEEE Ind. Electron., Mag., vol. 2, 28-39.

[9] J. Rodriguez, L.G. Franquelo, S. Kouro, J.I. Leon, R.C. Portillo, M.A.M. Prats, and M.A. Perez. (2009). Multilevel converters: An enabling technology for high-power applications, Proc. IEEE, vol. 97, no. 11, 1786-1819.

[10] S. Kouro, M. Malinovski, K. Gopakumar, J. Pou, L. G. Franquelo, B. Wu, J. Rodriguez, M. A. Perez, J. L. Leon. (2010). Resentadvances and industrial applications of multilevel converters. IEEE Trans.Ind.Electron., vol. 57, no.8, 2084-2096.

\section{Двигун 3 асинхронним фазним ротором в режимі компенсатора реактивної потужності}

\section{Ю. В. Ковальова}

Харківський національний університет міського господарства ім. О.М. Бекетова, Україна

\section{В. М. Ковальов}

Національний технічний університет "Харківський політехнічний інститут", Україна

\section{В. М. Фатєєв}

Харківський національний університет міського господарства ім. О.М. Бекетова, Україна

Компенсація реактивної потужності залишається важливим фактором енергозбереження. Зазвичай для компенсації використовують конденсерні батареї, недоліком яких є труднощі регулювання величини ємності при змінному споживанні реактивної потужності. Для плавного регулювання реактивної потужності використовуються синхронні двигуни та напівпровідникові статичні компенсатори. Але пошук використання інших альтернативних засобів компенсації реактивної потужності залишається актуальним. 


\section{МІЖНАРОДНИЙ ЖУРНАЛ «СВІТЛОТЕХНІКА ТА ЕЛЕКТРОЕНЕРГЕТИКА»}

Yu. Kovalova, V. Kovalov, V. Feteev, Вип.55, №02.

В якості альтернативного компенсатора реактивної потужності в статті пропонується використовувати асинхронний двигун 3 подвійним джерелом живлення. На першому етапі розглядається теоретичний аналіз процесу генерації реактивної потужності асинхронним двигуном подвійного живлення. При подвійному живленні до статора подається синусоїдальна напруга, а до ротора подається пряма напруга. У цьому випадку обмотка ротора перетворюється на електромагніт постійного струму, який обертається синхронно з обертовим магнітним полем, створеним фіксованими обмотками статора.

Магнітне поле обмотки ротора рухається відносно нерухомих обмоток статора зі швидкістю рухомого магнітного поля статора. Їх магнітні осі збігаються, тому що двигун працює на холостому ходу. Для обгрунтування режиму генерації реактивної потужності були складені векторні діаграми напруги та струму статора та ротора для трьох режимів роботи асинхронного двигуна з подвійним живленням: режиму споживання реактивної потужності, режиму не споживання та режиму генерації.

На другому етапі розробляються коло живлення та коло управління для асинхронного двигуна 3 подвійним живленням. Розроблено релейну схему для управління асинхронним двигуном 3 подвійним живленням. Проведено експериментальні дослідження для визначення залежності струму статора та його фазового зсуву відносно напруги статора від величини струму обмотки ротора.

За результатами експериментів побудовано графік залежності струму обмотки статора від величини постійного струму обмотки ротора. 3 графіка випливає, що зі збільшенням струму ротора струм статора змінюється. Спочатку струм статора зменшується до мінімального значення, а потім збільшується. Це означає, що тип струму статора змінюється від індуктивного до активного та до ємнісного.

Таким чином, використання асинхронного двигуна для генерування реактивної потужності має переваги перед батараями конденсаторів, оскільки дозволяє його плавне управління.

Ключові слова - асинхронний двигун, фазний ротор, подвійне живлення, реактивна потужність, компенсаиія. 